\title{
PELATIHAN SENI TARI PADA SISWA PASRAMAN SEBAGAI BENTUK TRANSFORMASI KEBUDAYAAN
}

\author{
Ni Wayan Ria Lestari'1), I Wayan Agus Gunada1) \\ 1)Program Studi Pendidikan Agama Hindu, STAHN Gde Pudja Mataran, Mataram, NTB, Indonesia \\ Corresponding author : I Wayan Agus Gunada \\ E-mail : gunadastahngpmataram@gmail.com
}

Diterima 31 Maret 2021, Disetujui 05 April 2021

\begin{abstract}
ABSTRAK
Tujuan penulisan hasil pengabdian kepada masyarakat dengan kegiatan pelatihan seni tari pada anakanak Pasraman merupakan bentuk implementasi keilmuan dalam proses transformasi kebudayaan dan nilai-nilai keagamaan Hindu. Istilah Kebudayaan berasal dari kata dalam bahasa sansekerta buddhayah yaitu bentuk jamak dari buddhi yang berarti budi atau akal. Salah satu kebudayaan yang sampai saat ini masih menjadi daya tarik wisatawan asing maupun negeri adalah seni gerak atau seni tari. Seni tari merupakan salah satu kesenian yang dapat meningkatkan kreatifitas siswa. Hal inilah yang menjadi acuan dalam pelaksanaan pelatihan seni tari bagi siswa Pasraman, sehingga para siswa mudah memahami dan mempraktekkan setiap gerakan tarian tersebut. Dalam proses pembelajaran di Pasraman, anak-anak sudah dibekali pengetahuan terkait seni tari, namun dalam pelatihan ini adalah memantapkan kembali pengetahuan anak-anak dalam sisi praktik kesenian. Teknis pelaksanaan kegiatan pelatihan seni tari ini dilakukan melalui model pelatihan dan pembimbingan secara langsung dengan menekankan kepada proses perancangan proses pelatihan sampai dengan evaluasi kegiatan pelatihan. Melalui tulisan ini sebagai bentuk pengimplementasian ilmu-ilmu yang diperoleh dalam pembelajaran dalam bentuk pengabdian sepenuhnya berlandaskan pada dharma dan yadnya, serta dapat memberikan gambaran terkait pelaksanaan kegiatan pelatihan dan dapat dilakukan kembali serta dapat menjadi kajian penelitian dimasa mendatang.
\end{abstract}

Kata kunci: pelatihan; seni; tari; kebudayaan.

\begin{abstract}
Writing the results of community service with dance art training activities in Pasraman children is a form of scientific implementation in the process of cultural transformation and religious values of Hinduism. Culture comes from Sanskrit buddhayah, which is the plural form of Buddhist meaning mind or reason. One of the cultures that are still an attraction for foreign and foreign tourists is the art of motion or dance. Dance is one of the skills that can increase students' creativity. This is the reference in implementing dance training for Pasraman students to understand and practice each dance movement quickly. In the learning process in Pasraman, children are equipped with knowledge related to dance, but this training is to reenter the understanding of children in art practice. Technical implementation of dance art training activities is carried out through a model of training and mentoring directly by emphasizing designing the training process up to the evaluation of training activities. As a form of implementation of the sciences obtained in learning in the form of devotion, this paper is entirely based on dharma and yadnya and can provide an overview related to the performance of training activities and can be done again and can be a research study in the future.
\end{abstract}

Keywords: training; art; dance; culture

\section{PENDAHULUAN}

Istilah pengabdian kepada masyarakat merupakan unsur wajib yang dilakukan oleh sebuah perguruan tinggi dalam tata kelola pendidikannya. Sehingga kegiatan pengabdian kepada masyarakat cukup penting untuk dilakukan sebagai media aplikasi dan penyebaran keilmuan. Dalam prosesnya pula kegiatan pengabdian dapat dilakukan dengan jalan pelatihan, penyuluhan, bimbingan teknis yang inti dari prosesnya adalah bentuk diseminasi pengetahuan pada kehidupan praktis di masyarakat.

Salah satu kegiatan yang dilakukan dalam proses pengabdian kepada masyarakat oleh Sekolah Tinggi Agama Hindu Negeri Gde Pudja Mataram yang dilaksanakan oleh Tim Pengabdian Prodi Pendidikan Agama Hindu adalah kegiatan pelatihan seni Tari. Pelatihan dan pembelajaran seni tari dalam proses 
perancangannya memiliki dua tujuan utama yaitu mengenalkan konsep-konsep tari Bali sebagai bentuk kebudayaan dan seni tari sebagai media pendidikan karakter Hindu. Apalagi dalam proses sejarahnya seni tari di Bali khususnya sangat dipengaruhi oleh pengaruh ajaran agama Hindu yang datang ke Bali (Iryanti, 2000), sehingga hal ini tentu dapat diasumsikan bahwa didalamnya terkandung ajaran-ajaran suci Hindu sehingga melalui ajaran Hindu tersebut maka penguatan karakter dilakukan dalam proses pelatihannya.

Manusia dan kebudayaan merupakan dua komponen yang berhubungan sangat erat yaitu manusia sebagai pelaku kebudayaan dan kebudayaan sebagai hasil olah cipta manusia yang akan berkembang dan berubah menjadi sebuah peradaban manusia di masa depan. Kesenian sebagai bagian dari kebudayaan tidak bisa dilepaskan dengan kehidupan masyarakat. Seni tari adalah salah satu bentuk karya seni dan kesenian bagian dari unsur dalam sistem kebudayaan Bali dan Nusantara yang berguna untuk meningkatkan kreativitas anak. Dimana pada pelaksanaannya dalam berlatih menari seorang anak bisa menuangkan emosi, ekpresi dan bebas berkreasi dengan mengkolaborasikan antara seni gerak dan seni musik.

Sebagai budaya warisan leluhur, dalam agama Hindu kesenian tari bukan hanya menjadi seni pertunjukan atau hiburan semata, tetapi seni tari sering dihubungkan dengan pelaksanaan upacara keagamaan maupun sebagai penangkal bala. Sesuai dengan keputusan "Seminar Seni Sakral dan Seni Profan Bidang Tari, yang berlangsung di Denpasar tanggal 24-25 Maret 1971, dilihat dari segi fungsinya seni tari dapat diklasifikasikan dalam tari Wali (religious dance), tari Bebali (cereminial dance) dan tari Balih-balihan (Djayus, 1980)

Tari Waliyang dimaksud dengan tari Wali ialah jenis seni tari sakral yang dilakukan di pura-pura dan di tempat-tempat yang ada hubungannya dengan upacara keagamaan dan sebagai pelaksana upacara yang hanya ditarikan pada hari-hari suci tertentu, Tari Bebali adalah seni tari yang difungsikan dan memiliki status sebagai pengiring dalam upacara serta upakara dalam setiap ritus pelaksanaan yadnya, Tari Balih-Balihan "Balih-balihan" adalah sebuah istilah yang dipergunakan untuk menyebutkan seni tari sekuler di Bali atau lebih kepada istilah profan (Suardana, Putra, \& Atmadja, 2018).

Seiring dengan perkembangan zaman, seni tari khususnya tari bali juga banyak mengalami dinamika atau perubahan namun perubahan dan perkembangan yang terjadi tetap menyesuaikan dengan unsur-unsur serta pakem-pakemnya dan penggunaan properti tradisional sehingga dalam proses pelatihannya mudah untuk diajarkan dan dipraktikkan oleh anak-anak dan masyarakat luas.

Pendidikan Pasraman sebagai salah satu jenis pendidikan keagamaan Hindu tentu menjadi media transfer dan transformasi dalam mengkorelasikan antara pengetahuan akademis dengan pengetahuan keagamaan bagi anak-anak Hindu. Jika dilihat kembali bahwa sistem pendidikan Hindu adalah sistem Pasraman atau aguron-guron yang menekankan kepada penguatan tujuan lahiriah dan batiniah yaitu penguatan nilai-nilai spiritualisme (Paramartha \& Yasa, 2017). Sehingga tentu dalam prosesnya maka karakter keHinduan menjadi fokus utama dalam pendidikan di Pasraman, dimana dalam ajaran agama Hindu nilai-nilai susila sebagai pedoman internalisasi karakter dapat dijumpai dalam teks-teks suci Hindu (Gunada, 2020).

Sehingga dalam prosesnya maka kegiatan pengabdian kepada masyarakat ini dilakukan pada Pasraman Amerta Sanjiwani di Desa Rincung, Kabupaten Lombok Barat. Pemilihan Pasraman sebagai lokasi pengabdian kepada masyarakat mengingat bahwa tujuan pelaksanaan pengabdian adalah internalisasi nilai-nilai ajaran agama Hindu dalam proses pendidikan yang tentu sangat sesuai dengan visi serta misi proses pendidikan keagamaan Hindu pada lembaga pendidikan Pasraman.

Secara pragmatis kemudian bahwa kegiatan pengabdian dengan mengambil kegiatan pelatihan seni tari diharapkan dapat memberikan manfaat yaitu untuk memberikan suasana baru kepada anak-anak Pasraman disaat bosan dalam proses pendidikan daring di masa pandemi covid-19, selain itu pula bahwa tari bali sebagai bagian dari kebudayaan Bali yang sangat kaya akan nilai-nilai ajaran agama Hindu akan dapat menjadi media penguatan pendidikan karakter bagi anak-anak. Tujuan kegiatan pengabdian kepada masyarakat ini juga sebagai bentuk diseminasi keilmuan lembaga dalam tujuannya untuk menjadi pusat kajian agama Hindu sehingga melalui kegiatankegiatan pengabdian maka implementasi ajaran-ajaran agama Hindu dapat dilakukan dan disebarkan bagi komunitas umat Hindu.

\section{METODE}

Pengabdian kepada masyarakat merupakan salah satu kegiatan yang penting karena merupakan aplikasi keilmuan dan implementasi ilmu dalam tataran teori pada tataran praktik (Gunada \& Pramana, 2021). Berkaitan dengan kegiatan pelatihan tari ini 
maka proses kegiatan pengabdian dilakukan dengan tetap mengedepankan aplikasi protokol kesehatan karena kegiatan pengabdian dilakukan pada masa-masa pandemi virus covid-19.

Dapat dijelaskan bahwa rangkaian kegiatan pengabdian kepada masyarakat dilakukan pada Pasraman Amerta Sanjiwani yang merupakan bentuk lembaga pendidikan keagamaan Hindu. Adapun waktu pelaksanaan dimulai pada tanggal 18-24 September 2020, sasaran kegiatan pengabdian kepada masyarakat pelatihan seni tari adalah anakanak peserta didik Pasraman yang berjumlah 40 siswa baik laki-laki dan perempuan.

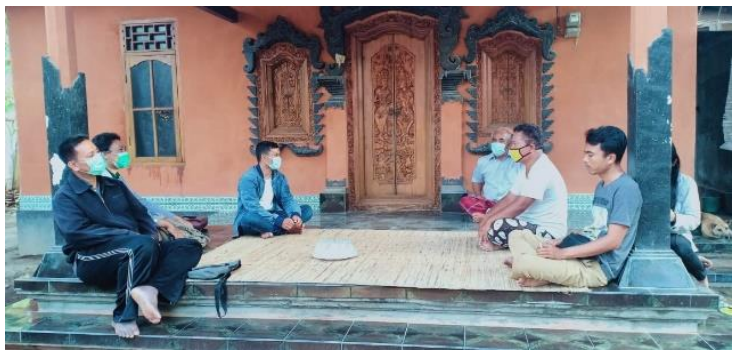

Gambar 1. Observasi Tim Pengabdian ke Lokasi Pasraman

Secara garis besar proses kegiatan dapat dijelaskan sebagai berikut : Tahap persiapan pelatihan seni tari pada siswa pesraman yaitu dimulai dengan mengadakan observasi ke lokasi kegiatan yaitu di Pasraman Amerta Sanjiwani, Dusun Rincung, Desa Banyu Urip, Kecamatan Gerung, Kabupaten Lombok Barat, Nusa Tenggara Barat seperti terlihat pada Gambar 1., dilanjutkan dengan pengadaan atau persiapan alat-alat penunjang yang diperlukan dalam pelaksanaan kegiatan pelatihan tari seperti sound system dan tempat pelaksaan kegiatan, penyusunan jadwal kegiatan untuk mencegah terjadinya benturan dengan kegitan yang lainnya.

Adapun tahap pelaksanakaan pelatihan tari pada siswa parsraman diantaranya : memilih siswa siswi yang akan mengikuti pelatihan tari, membagi peserta menjadi 2 kelompok, yaitu kelompok anak laki-laki dan perempuan. memitivasi dan memberikan arahan agar para siswa mengikuti dengan teratur dan mengikuti seluruh rangkaian kegiatan serta bersungguh-sungguh dalam mempraktekkannya dan melaksanakan pelatihan tari secara bertahap mulai dari Gerakan dasar sampai selesai.

Tingkat keberhasilan pelatihan ini bisa kita lihat dari kemampuan siswa dalam mempraktekkan seluruh gerakan dalam suatu tarian mulai dari gerakan dasar dan kekesuaian antara gerak tubuh, kepala, mata,tangan dan kaki sehingga siswa mampu membawakan sebuah tarian tanpa ada kasalahan. Secara garis besar proses kegiatan secara umum dapat dilihat pada diagram alir pada Gambar 2. Berikut :

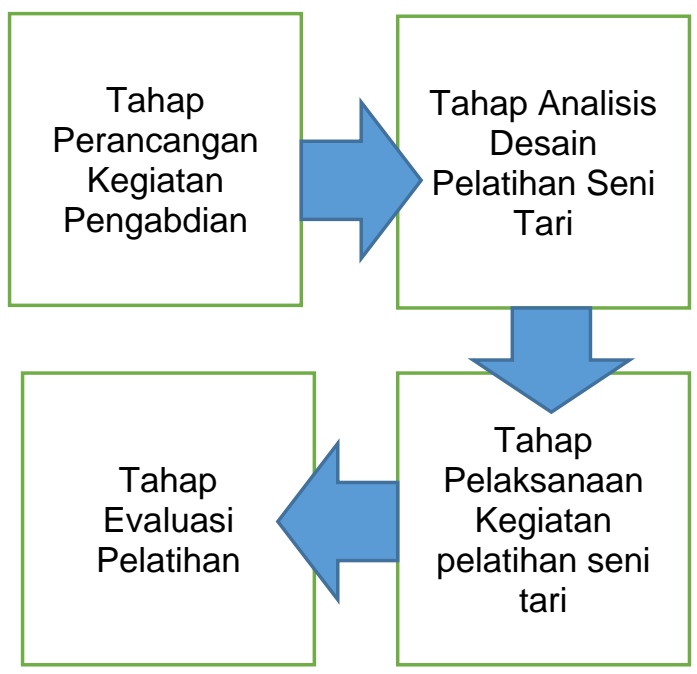

Gambar 2. Diagram Alir Kegiatan pada Pelatihan Tari Bali

\section{HASIL DAN PEMBAHASAN}

Rancangan pembelajaran seni tari pada siswa Pasraman meliputi pemantapan kembali seni tari yang telah diperoleh siswa berupa pelatihan dasar olah tubuh serta Teknik menari yang benar. Dengan adanya pelatihan ini diharapkan nantinya siswa Pasraman dapat terus mengambangkan kreativitas dan tetap melestarikan budaya leluhur. Pelatihan ini juga memberikan inovasi bagi para siswa agar nantinya mereka dapat menciptakan tari kreasi baru namun tidak menghilangkan unsur-unsur budaya tradisional yang menjadi dasar dalam mengembangkan tarian kreasi bernuansa modern.

Secara teori bahwa perkembangan dan pengaruh ajaran agama Hindu dalam seni tari begitu kuat, sehingga konsep, nilai-nilai dan ajaran agama Hindu juga ditemukan dalam konsep pembentukan tari bali yaitu konsep tri angga sebagai pengembangan ajaran tri hita karana, dalam gerakan-gerakannya maka terdapat dua jenis gerakan yaitu gerakan maknawi yang didalam gerakan-gerakannya mengandung berbagai nilai filosofis dan gerakan murni yang memang terbentuk karena nilai keindahan keseniannya (Dewi \& Satria, 2020).

Pada dasarnya pelatihan tari ini bertujuan untuk memantapkan kembali pengetahuan seni anak-anak Pasraman yang telah mereka peroleh dari para acarya (guru Pasraman). Namun pelatihan ini sebagai salah satu upaya untuk memantapkan kembali pengetahuan tersebut, sehingga anak-anak 
Pasraman lebih mudah dalam mempelajari dan memahami makna dari setiap gerakan yang terdapat dalam sebuah tarian.

Dalam sebuah kesenian, seni tari juga dibentuk berdasarakan elemen atau unsurunsur tertentu, terdapat banyak unsur yang terkandung dalam sebuah tarian, seperti musik (gambelan), busana, tata rias, tata panggung yang tentu berbeda antara tarian satu dan lainnya (Susanti, 2015). Diantara beberapa unsur tersebut terdapat satu unsur yang yang harus diperhatikan oleh seorang penari yaitu Gerakan dasar tari. Gerakan dasar ini melibatkan hampir semua bagian tubuh seperti kepala, mata, tangan sampai kaki. Dalam sebuah tarian terdapat dua gerakan dasar yaitu gerak stilatif dan distortif. Gerak stilatif merupakan proses mengolah suatu gerak tarian menjadi lebih halus dan indah. Sementara itu, gerak distorsif marupakan gerak tari yang diolah dengan mempertahankan keasliannya dan dirombak yang sering disebut stilasi (perubahan gerak tanpa meninggalkan gerak aslinya). Seperti yang terlihat pada Gambar 3 dan 4. berikut :

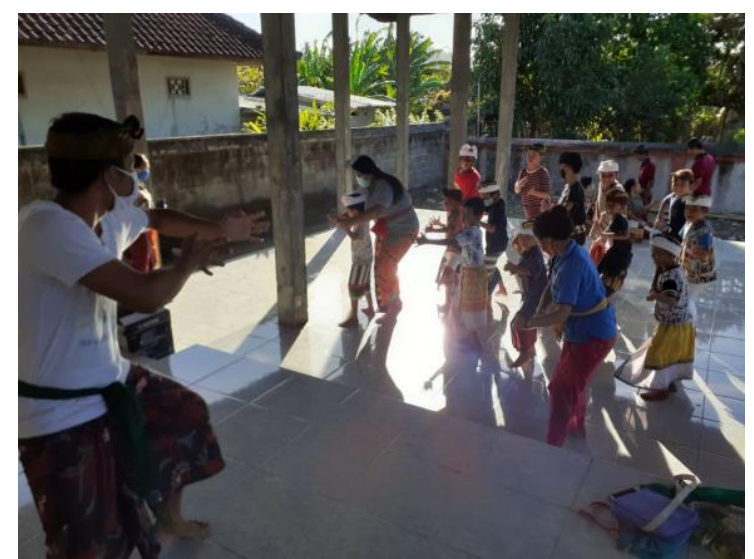

Gambar 3. Bentuk Gerakan Dasar Seni Tari pada anak laki-laki

Pelatihan yang tepat dan sesuai dalam sebuah pengajaran dan pelatihan seni tari tentu hal utama yang harus diperhatikan dan difokuskan oleh seorang pelatih tari. Hal ini dikarenakan dalam tari Bali begitu banyak gerakan-gerakan yang menjadi gerak dasarnya. Sehingga perlu adanya pemahaman dan pemilihan model pelatihan akan sangat menunjang dalam pembentukan keterampilan menari bagi anak-anak. Menurut teorinya bahwa terdapat sejumlah istilah nama gerak dasar tari bali diantaranya Ragam gerak itu antara lain Miles, Mungkah lawang, Agem, Seledet, Luk nerudut, Ngelangkar, Ngotog, Ulap-ulap, Ombak angkel, Ngejat pala, Ngelo, Nyeregseg, Ngumad, Ngumbang, Kidang rebut muring, Milpil, Lasan megat yeh, Ngepik, Tanjek panjang, Ngenjet, Ngubit, Gulungangsul,
Ngengsog, Ngelus, Ngeliput, Ngepel, Nyegut, Mentang laras, Durga, Ngelung kiri, Gelatik nuut papah, Lembu anongo (Erawati, 2018).

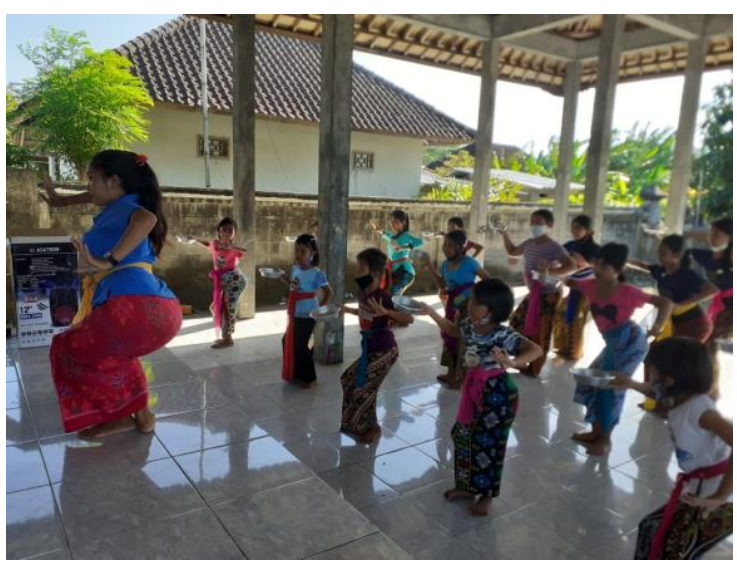

Gambar 4. Bentuk Gerakan Dasar Seni Tari pada anak perempuan

Dasar dari berlatih seni tari Bali adalah agem, Tandang dan tangkep (Dewantara, Crisnapati, Kesiman, \& Darmawiguna, 2013).

Istilah agem mengacu kepada makna sikap dasar, tandang adalah gaya mengacu kepada gerak gerik dan tandang adalah ekspresi yang menggambarkan emosi dalam gerakan (Dewi \& Satria, 2020). Agem merupakan sikap pokok dalam tari bali. Dalam tari bali agem dibedakan menjadi dua, yaitu agem kanan dan agem kiri (Dewi, Hartawan, \& Sukajaya, 2019). Terdapat perbedaan agem pada tari laki-laki dan tari perempuan yaitu terlihat dari visualisasinya yaitu bentuk dan sikap kaki serta sikap tangan dan bentuk sikap baik dari posisi bahu dan dada (Sama, 2013)

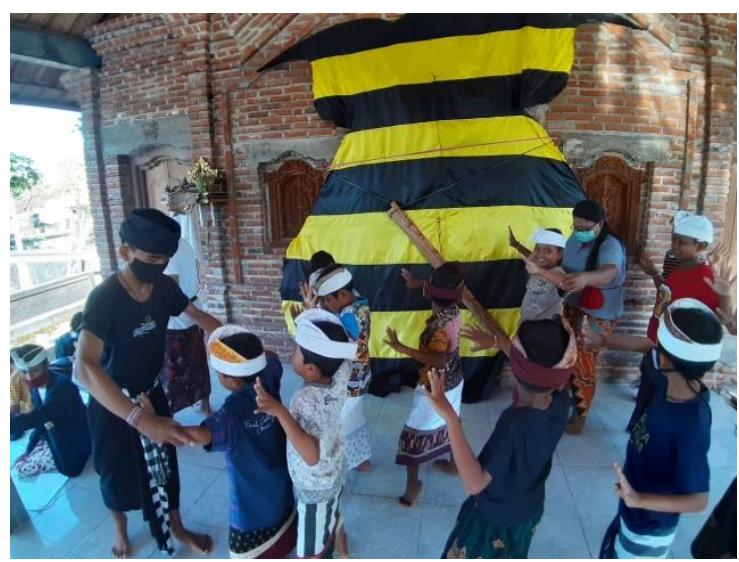

Gambar 5. Pembimbingan secara langsung oleh pelatih.

Dalam prosesnya pelatihan dilakukan dengan menggunakan pendekatan pembimbingan secara langsung oleh pelatih kepada seluruh peserta didik seperti yang terlihat pada Gambar 5. Hal ini sesuai dengan 
pendekatan internalisasi penguatan karakter bahwa dalam prosesnya harus tetap memperhatikan interaksi yang mendalam oleh pendidik kepada peserta didik sehingga tercipta pelibatan siswa yang aktif untuk mengembangkan penguatan karakter (Zubaedi, 2013).

Pada pelaksanaan pelatihan tari Bali bagi anak-anak maka dilakukan pula bentuk evaluasi secara langsung yaitu dengan mengamati sejauh mana peserta pelatihan mampu menyerap berbagai teori dan pengetahuan praktek. Dalam prosesnya juga dilakukan pelibatan peserta pelatihan secara aktif dengan melakukan model tutor sebaya dimana salah satu peserta pelatihan dijadikan sebagai seorang pelatih untuk melatih langsung teman-temannya terlihat seperti pada Gambar 6 .

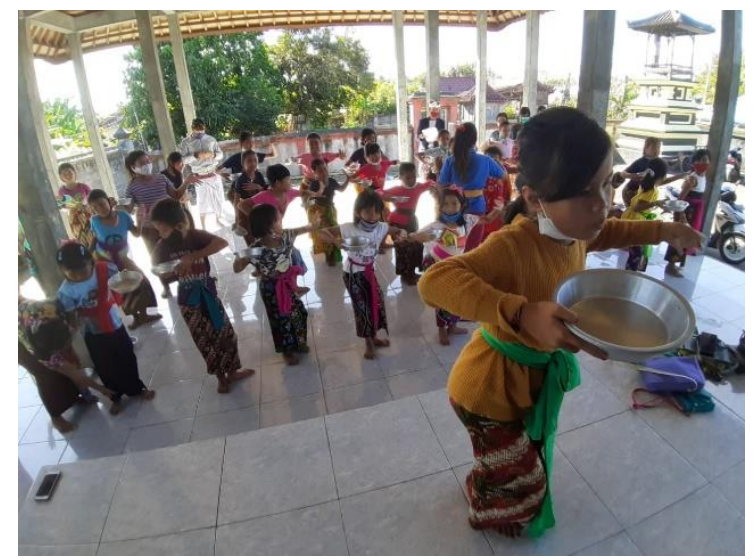

Gambar 6. Model Tutor Sebaya dalam pelatihan tari

\section{SIMPULAN DAN SARAN}

Melihat antusiasme dari anak-anak prasraman amerta sanjiwani dalam mengikuti kegiatan pelatihan tari, maka dapat disimpulkan bahwa kegiatan pengabdian kepada masyarakat ini dapat dikatakan berjalan lancar dan terlaksana sesuai yang diharapkan. Hal ini tidak terlepas dari dukungan banyak pihak terutama dari guru Pasraman, dan masyarakat sekitar. Namun tentu harus jujur dikatakan bahwa dengan situasi pandemi covid-19 dan protokol kesehatan yang harus diberlakukan sedikit banyaknya telah mempengaruhi proses pelatihan sehinggga dapat dikatakan proses pelatihan kurang maksimal namun sebagian besar sudah sesuai dengan yang dirancang.

$$
\text { Oleh karenanya untuk }
$$

memaksimalkan proses yang sudah berjalan tentu kegiatan pelatihan harus dilakukan secara terus menerus kedepannya. Partisipasi aktif antara tim pengabdian dan seulurh komponen masyarakat sebagai sasaran pengabdian kepada masyarakat dan anak-anak sebagai generasi penerus bangsa, sudah selayaknya anak diajarkan untuk melestarikan kebudayaan yang ada di daerahnya. Disinilah pentingnya sinergi antara orang tua dan masyakat untuk memfasilitasi keterampilan mereka sesuai dengan bakat dan minatnya sehingga kedepannya mereka akan mampu mengembangkan potensi yang ada di dalam dirinya. Sehingga harapannya keterampilan yang sudah dikuasai juga didalamnya timbul kesadaran untuk mengembangkan dan menguatkan karakter sebagai fokus utama dalam proses pendidikan.

\section{UCAPAN TERIMAKASIH}

Terima kasih diucapkan kepada lembaga STAHN Gde Pudja Mataram karena telah memberikan kesempatan kepada Tim untuk dapat melaksanakan kegiatan pengabdian. Terima kasih pula disampaikan kepada Pengurus dan seluruh komponen masyarakat di dusun Rincung, Kabupaten Lombok Barat dan Pasraman Amerta Sanjiwani karena telah turut serta dalam berperan dan membantu seluruh rangkaian kegiatan sehingga dapat berjalan sesuai dengan perencanaan.

\section{DAFTAR RUJUKAN}

Dewantara, I. M. A. Y., Crisnapati, P. N., Kesiman, M. W. A., \& Darmawiguna, I. G. M. (2013). Augmented Reality Book Pengenalan Gerak Dasar Tari Bali. Karmapati, 2(8), 27-33. https://doi.org/10.23887/karmapati.v2i8 .19764

Dewi, I. A. G. P., \& Satria, I. K. (2020). Konsep Tri Angga Dalam Belajar Teknik Tari Bali. Widyanatya: Jurnal Pendidikan Agama Dan Seni, 2(1), 39-46. https://doi.org/10.32795/widyanatya.v2i 01.625

Dewi, L. I. P., Hartawan, I. G. N. Y., \& Sukajaya, I. N. (2019). Etnomatematika Dalam Tari Bali Ditinjau Dari Klasifikasi Tari Bali. Jurnal Pendidikan Dan Pembelajaran Matematika Indonesia, 8(1), 39-48. https://doi.org/10.23887/jppm.v8i1.284 2

Djayus, I. N. B. . (1980). Teori Tari Bali (1st ed.). Denpasar: CV. Kayumas Agung.

Erawati, N. M. P. (2018). Mengenal Ragam Gerak Dan Jalinan Estetika Tari Bali. Widyadari: Jurnal Pendidikan, 19(2), 18. Retrieved from https://ojs.ikippgribali.ac.id/index.php/w idyadari/article/view/181

Gunada, I. W. A. (2020). Ajaran Agama Hindu Dalam Geguritan Candrabherawa Sebagai Penguatan Pendidikan 
Karakter. Kamaya: Jurnal IImu Agama, 3(2), $\quad$ 102-119. https://doi.org/10.37329/kamaya.v3i2.4 34

Gunada, I. W. A., \& Pramana, I. B. K. Y. (2021). Desain Pelatihan Menggambar Ornamen Bali Sebagai Implementasi Nilai Pendidikan Agama Hindu. Jurdimas (Jurnal Pengabdian Kepada Masyarakat, 4(1), 77-84. https://doi.org/10.33330/jurdimas.v4i1. 909

Iryanti, V. E. (2000). Tari Bali: Sebuah Telaah Historis. Harmonia - Journal of Arts Research and Education, 1(2), 75-90. https://doi.org/10.15294/harmonia.v1i2. 846

Paramartha, W., \& Yasa, I. W. S. (2017). Mengungkap Model Pendidikan Hindu Bali Tradisional Aguron-guron. Mudra, 32(1), $131-140$. https://doi.org/10.31091/mudra.v32i1.9 2

Sama, I. W. (2013). Estetika Tari Oleg Tamulilingan. Terob: Jurnal Pengkajian Dan Penciptaan Seni, 4(6), 114-123. https://doi.org/10.20111/st.v4i6.30

Suardana, G., Putra, i N. D., \& Atmadja, N. B. (2018). "The Legend of Balinese Goddesses": Komodifikasi Seni Pertunjukan Hibrid dalam Pariwisata Bali. Jurnal Kajian Bali (Journal of Bali Studies), $\quad$ 08(1), 35-52. https://doi.org/10.24843/JKB.2018.v08. i01.p03

Susanti, D. (2015). Analisis Tari Manjolang Sonjo Di Kecamatan Kuok Kabupaten Kampar Propinsi Riau. Koba: Jurnal Pendidikan Seni Drama, Tari Dan Musik, 02(2), 62-72. Retrieved from https://journal.uir.ac.id/index.php/koba/ article/view/1213

Zubaedi. (2013). Desain Pendidikan Karakter (1st ed.; Zubaedi, Ed.). Jakarta: Kencana Prenada Media Group. 